DOI 10.22460/jpmi.v1i3.371-382

\title{
ASOSIASI ANTARA KEMAMPUAN GENERALISASI MATEMATIK DENGAN SELF-CONCEPT SISWA SMP YANG MENGGUNAKAN STRATEGI PEMBELAJARAN BERBASIS VBA MICROSOFT EXCEL
}

\author{
Citra Megiana Pertiwi ${ }^{1}$, Risa Amelia Jayanti ${ }^{2}$, Muhammad Afrilianto ${ }^{3}$ \\ 1,2,3 IKIP Siliwangi, Jl. Terusan Jenderal Sudirman, Cimahi, Jawa Barat, Indonesia \\ 1 citra.megianapertiwi@gmail.com, ${ }^{2}$ risaameliaj@ gmail.com, \\ ${ }^{3}$ muhammadafrilianto1@ikipsiliwangi.ac.id
}

Diterima: 17 April 2018; Disetujui: 28 Mei 2018

\begin{abstract}
The purpose of this research is to find the correlation between mathematical generalization skill and student's self-concept in learning activities by using learning strategy based on VBA's Microsoft Excel. Experimental method is used in the research with 2 different classes. The first class is given by VBA Microsoft Excel learning based, while the other class is given common learning method. In addition, the data sample used in this research are all Junior High School in Cimahi, one school is selected randomly and SMP Negeri 4 Cimahi has been selected. The Sample chosen is the $8^{\text {th }}$ grade pupils which selected randomly. The result of the research is obtained from mathematical generalization skill test instrument of phytagoras and self-concept skill inquiry as non-test instrument. Mathematical generalization skill post-test result and final inquiry are analyzed by using Spearman to find the correlation. The result shows that there is a correlation between mathematical generalization skill and student's self-concept in learning mathematics.
\end{abstract}

Keywords: Mathematical Generalization Ability, Self-Concept, VBA Microsoft Excel

\begin{abstract}
Abstrak
Tujuan dari penelitian ini adalah untuk menelaah bagaimana asosiasi antara kemampuan generalisasi matematik dengan self-concept siswa dalam pembelajaran yang menggunakan strategi pembelajaran berbasis VBA Microsoft Excel. Metode yang digunakan adalah metode eksperimen, dengan diambil dua kelas yang berbeda, dimana kelas eksperimen memperoleh pembelajaran berbasis VBA Microsoft Excel dan kelas kontrol memperoleh pembelajaran seperti biasanya. Populasi dalam penelitian ini adalah seluruh SMP Negeri di Kota Cimahi, dari seluruh SMP Negeri di Kota Cimahi dipilih salah satu sekolah secara acak, dan terpilihlah SMP Negeri 4 Cimahi. Sampel pada penelitian ini adalah kelas VIII di SMP Negeri 4 Cimahi yang dipilih dua kelas secara acak. Untuk mendapatkan data hasil penelitian digunakan instrumen berupa tes kemampuan generalisasi matematik tentang phytagoras dan non-tes berupa angket kemampuan self-concept. Hasil posttest tes kemampuan generalisasi matematik dan angket akhir di analisis korelasinya menggunakan Spearman. Hasil penelitian menunjukkan adanya asosiasi antara kemampuan generalisasi matematik dan self-concept siswa dalam pembelajaran matematika.
\end{abstract}

Kata Kunci: Kemampuan Generalisasi Matematis, Self-Concept, VBA Microsoft Excel

How to cite: Pertiwi, C. M., Jayanti, R. A., \& Afrilianto, M. (2018). Asosiasi antara Kemampuan Generalisasi Matematik dengan Self-Concept Siswa SMP yang menggunakan Strategi Pembelajaran Berbasis VBA Microsoft Excel. JPMI - Jurnal Pembelajaran Matematika Inovatif, 1 (3), 371-382. 


\section{PENDAHULUAN}

Perkembangan ilmu pengetahuan dan teknologi sebagai upaya dalam menghadapi segala tantangan masa depan tidak terlepas dari peran matematika, salah satunya adalah kemampuan penalaran yang dinilai sangat penting karena merupakan bagian dari kemampuan matematik tingkat tinggi yang memiliki peranan dalam pengambilan suatu keputusan. Hal ini senada dengan tujuan pembelajaran matematika yang dirumuskan oleh Kemendikbud (Ario, 2016) yaitu menggunakan proses penalaran pada pola dan sifat, tindakan manipulasi matematika dalam membuat suatu generalisasi, menyusun pembuktian, atau menjelaskan gagasan dan pernyataan matematika. Kegiatan pembelajarannya berupa mengamati, menanya, mencoba, menalar, menyaji, dan mencipta yang mengajarkan siswa untuk menjadi kritis dalam analisisnya. Dengan demikian keberhasilan seorang pelajar dalam pendidikan dapat ditinjau dari bagaimana kemampuan pelajar dalam menggapai tujuan pembelajaran (Hendriana, Hidayat, \& Ristiana, 2018; Hendriana, Rohaeti, \& Hidayat, 2017).

Kemudian Sumarmo (Haerudin, 2013) memaparkan, "Penalaran merupakan proses berpikir dalam proses penarikan kesimpulan”. Kemampuan penalaran matematik dibagi menjadi dua bagian, yaitu penalaran induktif dan penalaran deduktif. Dari kedua jenis penalaran ini terdapat satu aspek yang merupakan bagian esensial dalam proses berpikir matematik, yaitu generalisasi. Generalisasi merupakan penarikan kesimpulan dari bukti-bukti khusus menuju kesimpulan umum. Di masa yang akan datang kemampuan ini sangat diperlukan siswa dalam segala aspek kehidupan namun masih banyak tanggapan bahwa kemampuan ini terbatas pada konsep matematika yang berorientasi pada angka dan perhitungannya..

Keberhasilan siswa dalam proses pembelajaran tidak hanya dipengaruhi oleh kemampuan kognitif berupa kemampuan generalisasi saja, namun ada salah satu faktor afektif yang sangat berpengaruh yaitu self-concept siswa. Self-concept sangat penting dimiliki siswa karena akan menjadikan siswa lebih bertanggung jawab dalam bertindak, utamanya dalam belajar, optimis dalam menyelesaikan soal-soal yang menantang, bahkan dapat mempengaruhi temannya untuk memiliki pandangan positif terhadap matematika.. Sejalan dengan pernyataan Rahman (2010) mengatakan, "Self-concept adalah suatu gabungan dari pandangan seseorang mengenai dirinya sendiri sebagai hasil interaksi antar individu dan lingkungannya. Interaksi ini menjadi penting guna mengkontruksi pengetahuan matematis, mengembangkan kompetensi pemecahan masalah, mendorong rasa percaya diri serta memperoleh keahlian sosial."

Beberapa hasil penelitian menunjukkan bahwa siswa SMP memiliki kemampuan generalisasi matematik dan self-concept yang rendah. Hasil penelitian yang dilakukan oleh Supandi (2017) menjelaskan bahwa kemampuan generalisasi matematik siswa tergolong masih rendah. Kemudian penelitian Priatna (Nuridawani, Munzir, \& Saiman, 2015) menyatakan bahwa kualitas kemampuan penalaran (analogi dan generalisasi) siswa yang berasal dari sekolah kluster baik, sedang dan kurang masih dinyatakan rendah. Penelitian Rahman (2010) yang menyatakan, "...hasil tes awal menunjukkan bahwa kemampuan generalisasi matematik siswa berada pada kedudukan kurang”. Selain itu penelitian yang dilakukan oleh Muyana (2017) menyatakan bahwa siswa yang memiliki self-concept rendah meskipun berimbang namun tergolong tinggi. Hal tersebut sejalan dengan penelitian Widiarti (2017) dengan hasil berimbang namun self-concept siswa yang rendah masihlah sangat tinggi. Rendahnya kemampuan generalisasi ini menjadi indikasi bahwa pembelajaran matematika belum tercapai secara maksimal sehingga diperlukan proses pembelajaran yang berkualitas guna menjadi solusi dalam mengatasi hambatan tersebut. 
Dalam upaya peningkatan kemampuan generalisasi matematik dan self-concept siswa SMP terdapat banyak pendekatan/strategi/metode/teknik mengajar yang bervariasi. Strategi pembelajaran yang diyakini mampu membina kompetensi siswa dalam meningkatkan kemampuan generalisasi matematik dan self-concept siswa adalah dengan menggunakan pembelajaran berbasis Information Communication and Technology (ICT) Visual Basic Aplication Microsoft Excel. Keunggulan dari pembelajaran ini adalah pembelajaran yang lebih interaktif, alat peraga yang memiliki karakteristik benda-benda semi konkret dan dapat dimanipulasi langsung oleh pendidik atau siswa dalam proses pembelajaran melalui pengubahan media pembelajaran konkret ke dalam bentuk media pembelajaran berbasis ICT, sebagai contoh pembuatan media pembelajaran maya untuk materi pembuktian teorema pythagoras.

\section{Kemampuan Generalisasi Matematik}

Penjelasan tentang kemampuan generalisasi matematik sudah banyak dipaparkan oleh para ahli. Soekadijo (2003) memaparkan bahwa "generalisasi adalah penalaran yang menyimpulkan suatu pernyataan yang bersifat umum dari asumsi-asumsi berbentuk proporsi matematik". Shurter dan Pierce (Lestari, 2015) menyatakan bahwa generalisasi adalah proses penalaran yang dihasilkan dari pegujian contoh secukupnya menuju sebuah kesimpulan mengenai semua atau beberapa contoh. Hal tersebut sejalan dengan pendapat Mundiri (Yuliani, 2011) yang menyatakan “...generalisasi sebagai proses menalar yang bertolak dari sejumlah fenomena individu menuju kesimpulan umum yang mengikuti seluruh fenomena sejenis dengan fenomena individu yang diselidiki”. Kemudian Depdiknas (Wahyuddin, 2017) berpendapat bahwa "...dalam pembelajaran matematika agar mudah dimengerti oleh siswa, proses penalaran induktif dapat dilakukan pada awal pembelajaran dan kemudian dilanjutkan dengan proses penalaran deduktif untuk menguatkan pemahaman yang sudah dimiliki oleh siswa".

Dari beberapa pemaparan tersebut dapat diambil kesimpulan bahwa generalisasi merupakan penarikan kesimpulan dari prihal-prihal khusus menjadi simpulan umum dengan cara mengambil suatu hubungan terkait dari keadaan khusus tersebut yang didasarkan pengetahuan atau informasi yang tersedia sehingga diperolah suatu kesimpulan yang memiliki sifat umum dan berlaku untuk keseluruhan.

Terdapat 4 indikator kemampuan generalisasi matematis menurut Mason (Lestari, 2015), yaitu sebagai berikut.

a. Perception of generality, atau dapat mengenal sebuah pola.

b. Expression of generality, atau mampu menjabarkan suatu aturan/pola, baik secara numerik maupun bahasa.

c. Symbolic expression of generality, atau mampu menerapkan suatu sebuah aturan atau pola umum.

d. Manipulation of generality, atau mampu menerapkan aturan/pola dari berbagai persoalan.

Kemudian Soekadijo (2003) memaparkan bahwa ada beberapa syarat-syarat terjadinya generalisasi, yaitu sebagai berikut.

a. Generalisasi tidak terbatas secara numerik, artinya generalisasi tidak dibolehkan adanya keterkaitan terhadap kuantitas tertentu. 
b. Generalisasi tidak terbatas secara spasio-temporal, artinya tidak terbatas dalam ruang dan waktu. Oleh karena itu aturan ini harus berlaku di mana pun dan kapan pun.

c. Generalisasi merupakan proses bernalar yang berdasarkan pada pemeriksaan terhadap halhal secukupnya kemudian diperoleh suatu kesimpulan untuk keseluruhan atau beberapa bagian hal-hal tadi dijadikan dasar pengandaian.

\section{Self-Concept}

Konsep diri atau self-concept menurut Yusuf dan Nurihsan (Hendriana, Rohaeti, \& Sumarmo, 2017), "Konsep diri sebagai; a) presepsi, keyakinan, perasaan atau sikap seseorang terhadap dirinya; b) kualitas sifat individu tentang dirinya; dan c) pandangan oranglain terhadap dirinya." Sedangkan menurut Symonds (Hendriana et al., 2017) menjelaskan, "Konsep diri yaitu: a) pandangan terhadap dirinya; b) pemikiran tentang dirinya; c) penilaian tentang dirinya; d) perbuatantentang kemajuan dirinya." Pengertian yang serupa, dikemukakan Hurlock (Hendriana et al., 2017) yang mendefinisikan, "Konsep diri sebagai pandangan seseorang mengenai dirinya sendiri yang mencakup fisik, psikologis, sosial, emosional, aspirasi dan prestasi yang telah dicapainya."

Self-Concept berperan dalam pengembangan potensi seseorang untuk mengeksplor secara maksimal potensi orang tersebut. Leonard dan Supardi (Rayani, 2017) memaparkan bahwa self-concept bukan merupakan faktor yang dibawa sejak lahir melainkan faktor yang dijiwai dan terbentuk melalui pengalaman individu dalam berkorelasi dengan orang lain. Lebih lanjut lagi, Berk (Widiarti, 2017) menjelaskan bahwa perkembangan konsep diri yang dialami oleh seseorang diawali dari usia 2 tahun (ada pengakuan dan identifikasi diri dengan melihat dirinya di kaca, foto, dan media lainnya); masa kanak-kanak awal (konsep dirinya bersifat kongkrit, biasanya berdasar karakteristik nama, penampilan fisik, barang-barang milik dan tingkah laku sehari-hari); masa kanak-kanak pertengahan (ada transformasi dalam pemahaman diri, mulai menjelaskan diri dengan istilah-istilah sifat kepribadian, mulai dapat membandingkan karakteristik dirinya dengan sebuah perbandingan).

Liu (Muyana, 2017) mengemukakan beberapa model self-concept dan prestasi akademik individu, yaitu (a) peningkatan diri, (b) pengembangan keterampilan, dan (c) efek timbal balik. Pada model peningkatan diri, self-concept merupakan penentu prestasi akademik siswa yang berarti pretasi akademik ini adalah hasil dari self-concept yang baik. Sebaliknya, pada model pengembangan keterampilan, self-concept adalah hasil dari prestasi akademik. Sehingga secara keseluruhan dalam model ini self-concept dan akademik siswa akan saling menguatkan.

Ada faktor-faktor yang dapat mempengaruhi self-concept siswa. Rahman (2010) memaparkan faktor yang memengaruhi self-concept sebagai berikut.

a. Keadaan fisik dan pandangan orang lain tentang keadaan fisik individu, dalam hal ini meliputi bentuk tubuh, kecacatan, kondisi tubuh termasuk kesehatan tubuh dan jenis kelamin.

b. Faktor psikologis, antara lain: intelegensi, tingkat aspirasi, emosi nama dan nama panggilan.

c. Faktor keluarga, antara lain: sikap orang tua, sikap saudara, status anak dalam keluarga serta kedudukan sosial dan ekonomi dalam keluarga.

d. Faktor lingkungan sekolah, meliputi: guru, siswa lain dan kegiatan ekstrakulikuler.

e. Faktor masyarakat, antara lain: pola kebudayaan dan status sosial. 
Kemudian terdapat indikator self-concept menurut Sumarmo (Hendriana et al., 2017) yaitu sebagai berikut.

a. Kesungguhan, ketertarikan, berminat: menunjukkan kemauan, keberanian, kegigihan, keseriusan, ketertarikan dalam belajar dan melakukan kegiatan matematika

b. Mampu mengenali kekuatan dan kelemahan diri sendiri dalam matematika

c. Percaya diri akan kemampuan diri dan berhasil melaksanakan tugas matematikanya

d. Bekerja sama dan toleran kepada orang lain

e. Menghargai opini orang lain dan diri sendiri

f. Berperilaku sosial: menunjukkan kemampuan berkomunikasi dan tahu menempatkan diri

g. Memahami manfaat belajar matematika, kesukaan terhadap belajar matematika.

\section{Pembelajaran Berbasis ICT VBA Microsoft Excel}

Dalam sebuah pembelajaran khususnya pembelajaran matematika perlu adanya inovasi agar pembelajaran lebih menarik untuk disimak dan dapat meningkatkan kualitas pemahaman siswa. Salah satu inovasi yang dapat dijadikan solusi adalah melalui media pembelajaran berbasis ICT dengan menggunakan Software Microsof Excel dan Visual Basic of Application. Microsoft Excel adalah salah satu program komputer yang dapat digunakan untuk menghitung, memproyeksikan, menganalisis serta mempresentasikan suatu data. Menurut Kusrianto (Nurhayati, 2015) "Microsoft Excel dapat dimanfaatkan untuk memvisualisasi berbagai model matematika karena Microsoft Excel memberikan fasilitas grafik yang cukup bervariasi". Salah satu fungsi VBA Microsoft Excel yaitu dapat membuat suatu aplikasi khususnya aplikasi untuk pembelajaran matematika. Konsep-konsep matematika dapat divisualisasikan dengan menggunakan aplikasi tersebut.

Kemudian menurut Arifin \& Nuroso (2011), “...bahasa makro Microsoft Excel (VBA) memberikan fasilitas bagi pengguna untuk menyusun program-program aplikasi yang lebih kompeks seperti layaknya menyusun program komputer dengan menggunakan bahasa-bahasa pemrograman." Sehingga pembelajaran matematika dengan menggunakan Microsoft Excel dan Visual Basic for Aplication dapat memudahkan siswa dalam penerapan konsep matematika, sehingga dapat meningkatkan kemampuan generalisasi matematik dan selfconcept siswa.

\section{METODE}

Metode yang digunakan dalam penelitian ini adalah penelitian eksperimen dengan disain dalam bentuk pretest-posttest Control Group Design. Penelitian ini melibatkan dua kelompok, yaitu kelompok eksperimen dan kelompok kontrol. Semua kelompok diberi pretest dan posttest. Kelompok eksperimen memperoleh pembelajaran matematika dengan strategi pembelajaran berbasis VBA Microsof Excel sebagai perlakuan dan kelompok kontrol memperoleh pembelajaran matematika seperti biasa sebagai perlakuan. Selain itu, variabel bebasnya dimanipulasikan. Menurut Ruseffendi (2010), desain penelitian digambarkan sebagai berikut: 


$\begin{array}{llll}\text { A } & 0 & X & 0 \\ \text { A } & 0 & & 0\end{array}$

Keterangan:

A : Pengambilan sampel dilakukan secara acak menurut kelas.

$0 \quad$ : Tes kemampuan generalisasi matematik dan angket self-concept.

$\mathrm{X} \quad$ : Pembelajaran dengan strategi pembelajaran berbasis VBA Microsoft Excel

Populasi dalam penelitian ini adalah seluruh siswa SMP Negeri di Kota Cimahi dengan subjek sampel adalah kelas VIII. Dari seluruh SMP Negeri di Kota Cimahi dipilih secara acak dan terpilih SMP Negeri 4 Cimahi selanjutnya dilakukan pemilihan sampel sebanyak dua kelas secara acak kelas. Di mana kelas pertama yaitu kelas VIII A yang pembelajarannya menggunkan strtategi pembelajaran berbasis VBA Microsoft Excel atau disebut kelas eksperimen sedangkan kelas kedua yaitu kelas VIII B yang pembelajarannya menggunkan pembelajaran biasa atau disebut kelas kontrol.

Instrumen yang digunakan dalam penelitian ini adalah berupa instrumen tes dan non tes. Instrumen tes berupa tes kemampuan generalisasi matematik yang dibuat berdasarkan materi yang terdapat dalam Kurikulum 2013 yaitu teorema phytagoras yang akan diintegrasi dengan indikator kemampuan generalisasi matematik untuk mengukur kemampuan generalisasi matematik siswa. Soal yang diujikan pada pretes dan postes adalah soal yang sama. Instrumen tes yang berbentuk soal uraian sebanyak 3 soal, sedangkan instrumen non tes berupa angket skala sikap tentang self-concept sebanyak 32 pernyataan.

\section{HASIL DAN PEMBAHASAN}

\section{Hasil}

Hipotesis dalam penlitian ini yaitu "Terdapat asosiasi antara kemampuan generalisasi matematik dan sel-concept siswa SMP dalam pembelajaran yang menggunakan strategi pembelajaran berbasis VBA Microsof Excel". Untuk menguji hipotesis tersebut, maka dilakukan uji korelasi. Sebelum menguji korelasi terlebih dahulu dilakukan uji normalitas sebagai prasyarat, jika data berdistribusi normal maka dilanjutkan dengan uji korelasi Product Moment Pearson dan jika data tidak berdistribusi normal maka digunakan uji korelasi spearman.

\section{Uji Normalitas Data Posttest Kelas Kontrol}

Uji normalitas yang digunakan dalam penelitian ini adalah uji Kolmogorov-Smirnov. Hipotesisnya:

$H_{0}$ : Data berdistribusi normal.

$H_{1}$ : Data tidak berdistribusi normal.

Kriteria pengujiannya adalah jika nilai sig. $>0,05$ maka data berdistribusi normal. Hasil uji normalitas dengan menggunakan software SPSS 23 terdapat pada Tabel 1. 
Tabel 1. Uji Normalitas Data Posttest Kemampuan Generalisasi Matematik dan Self-Concept Kelas Kontrol

\begin{tabular}{lcccccc}
\hline \multicolumn{1}{c}{ Instrumen } & $\mathbf{N}$ & $\overline{\boldsymbol{x}}$ & $\mathbf{S}$ & Statistic & Sig. & Interpretasi \\
\hline Kemampuan generalisasi & 30 & 5.80 & 1.990 & 0.190 & 0.007 & Tidak Normal \\
matematik & 30 & 90.63 & 7.531 & 0.114 & 0.200 & Normal \\
Angket self-concept & & & & &
\end{tabular}

Berdasarkan Tabel 1 sesuai dengan kriteria pengujian maka untuk sampel kelas kontrol data kemampuan generalisasi matematik tidak berdistribusi normal sedangkan data angket selfconcept berdistribusi normal.

\section{Uji Normalitas Kelas Eksperimen}

Uji normalitas yang digunakan dalam penelitian ini adalah uji Kolmogorov-Smirnov. Hipotesisnya:

$H_{0}$ : Data berdistribusi normal.

$H_{1}$ : Data tidak berdistribusi normal.

Kriteria pengujiannya adalah jika nilai sig. > 0,05 maka data berdistribusi normal. Hasil uji normalitas dengan menggunakan software SPSS 23 terdapat pada Tabel 2.

Tabel 2. Uji Normalitas Data Posttest Kemampuan Generalisasi Matematik dan Self Concept Kelas Eksperimen

\begin{tabular}{lcccccc}
\hline \multicolumn{1}{c}{ Instrumen } & $\mathbf{N}$ & $\overline{\boldsymbol{x}}$ & $\mathbf{S}$ & Statistic & Sig. & Interpretasi \\
\hline Kemampuan generalisasi & 29 & 10.90 & 1.047 & 0.263 & 0.000 & Tidak Normal \\
matematik & 29 & 96.38 & 8.658 & 0.161 & 0.053 & Normal \\
Angket self-concept & & & &
\end{tabular}

Berdasarkan Tabel 2 sesuai dengan kriteria pengujian maka untuk sampel kelas eksperimen data kemampuan generalisasi matematik tidak berdistribusi normal sedangkan data angket self -concept berdistribusi normal.

\section{Uji Korelasi Kemampuan Generalisasi Matematik dan Self-Concept}

Pada perhitungan sebelumnya telah diketahui bahwa data kelas eksperimen dan kelas control tidak berdistribusi normal. Untuk mengetahui seberapa kuat asosiasi antara kemampuan generalisasi matematik dan self-concept siswa dalam matematika digunakan uji korelasi spearman dengan taraf signifikansi 0,05 . 
378 Pertiwi, Jayanti, \& Afrilianto, Asosiasi antara Kemampuan Generalisasi Matematik ...

\section{Kelas kontrol}

Hipotesis yang akan diuji:

$\mathrm{H}_{0}$ : tidak terdapat asosiasi antara kemampuan generalisasi matematik dan self-concept siswa kelas kontrol

Ha : terdapat asosiasi antara kemampuan generalisasi matematik dan self-concept siswa kelas kontrol

Kriteria pengujiannya adalah jika nilai sig.(2-tailed) > 0,05 maka Ho diterima. Hasil uji korelasi dengan menggunakan software SPSS 23 terdapat pada Tabel 3.

Tabel 3. Hasil uji korelasi data posttest kemampuan generalisasi matematik dan self-concept siswa kelas kontrol

\begin{tabular}{lccc}
\hline \multicolumn{1}{c}{ Instrumen } & N & Spearman Correlation & Sig.(2-tailed) \\
\hline $\begin{array}{l}\text { Kemampuan generalisasi } \\
\text { matematik }\end{array}$ & 30 & 1.000 & 0.463 \\
Angket self-concept & 30 & 0.139 & \\
\hline
\end{tabular}

Berdasarkan Tabel 3 sesuai dengan kriteria pengujian maka untuk sampel kelas kontrol menunjukkan tidak terdapat asosiasi antara kemampuan generalisasi matematik dan selfconcept siswa kelas kontrol.

\section{Kelas Eksperimen}

Hipotesis yang akan diuji:

Ho : tidak terdapat asosiasi antara kemampuan generalisasi matematik dan self-concept siswa kelas eksperimen.

Ha : terdapat asosiasi antara kemampuan generalisasi matematik dan self-concept siswa kelas eksperimen.

Kriteria pengujiannya adalah jika nilai sig.(2-tailed) > 0,05 maka Ho diterima. Hasil uji korelasi dengan menggunakan software SPSS 23 terdapat pada tabel 4.

Tabel 4. Hasil uji korelasi data posttest kemampuan generalisasi matematik dan self-concept siswa kelas eksperimen

\begin{tabular}{lccc}
\hline \multicolumn{1}{c}{ Instrumen } & N & Spearman Correlation & Sig.(2-tailed) \\
\hline $\begin{array}{l}\text { Kemampuan generalisasi } \\
\text { matematik }\end{array}$ & 29 & 1.000 & 0.039 \\
\begin{tabular}{l} 
Angket self-concept \\
\hline
\end{tabular} & 29 & 0.386 & \\
\hline
\end{tabular}

Berdasarkan Tabel 4 sesuai dengan kriteria pengujian maka untuk sampel kelas kontrol menunjukkan terdapat asosiasi antara kemampuan generalisasi matematik dan self-concept siswa kelas eksperimen. 


\section{Pembahasan}

Pembahasan hasil penelitian ini didasarkan pada data yang telah dianalisis pada sub bab sebelumnya dan temuan-temuan dilapangan mengenai kemampuan generalisasi matematik dan self-concept, serta media pembelajaran berbasis VBA Microsoft Excel. Pada pertemuan terakhir penelitian, siswa pada kelas eksperimen dan kelas kontrol diberikan posttest dengan maksud untuk mengetahui kemampuan akhir siswa setelah memperoleh pembelajaran. Hasil posttest menunjukkan bahwa rata-rata kemampuan generalisasi siswa pada kelas eksperimen yang memperoleh pembelajaran dengan VBA Microsoft Excel memperoleh nilai yang lebih tinggi dibandingkan dengan kelas kontrol yang memperoleh pembelajaran biasa. Selain itu, nilai rata-rata self-concept siswa yang memperoleh pembelajaran berbasis VBA Microsof Excel lebih besar dari kelas yang memperoleh pembelajarn biasa. Kondisi tersebut menunjukkan bahwa sangat berpengaruh antara kemampuan generalisasi matematik dan selfconcept siswa.

Berdasarkan Tabel 3, diperoleh hasil uji korelasi antara kemampuan generalisasi matematik dan self-concept siswa kelas kontrol memiliki nilai koefisen korelasinya sebesar 0,139 yang termasuk klasifikasi rendah. Nilai signifikansi sebesar 0,463 lebih besar dari 0,05 menunjukkan tidak terdapat asosiasi yang signifikan antara kemampuan generalisasi matematik dan self-concept siswa kelas kontrol. Berdasarkan tabel 4, diperoleh hasil uji korelasi antara kemampuan generalisasi matematik dan self-concept siswa kelas eksperimen memiliki nilai koefisen korelasinya sebesar 0,386 yang termasuk klasifikasi cukup. Nilai signifikansi sebesar 0,039 lebih kecil dari 0,05 menunjukkan terdapat asosiasi yang signifikan antara kemampuan generalisasi matematik dan self-concept siswa kelas eksperimen.

Hal ini salah satunya dimungkinkan karena adanya kesesuaian antara materi pembelajaran dan strategi pembelajaran yang digunakan, terlebih pembelajaran berbasis VBA Microsof Excel menjadikan aktivitas belajar lebih interaktif dan kreatif, Pembelajaran yang terjadi di kelas ekperimen siswa terlihat lebih semangat dan memperhatikan pembelajaran serta berani mencoba dan tampil di depan kelas, sehingga penemuan konsep hingga penarikan kesimpulan matematika akan lebih mudah bagi siswa. Dari analisis tersebut menunjukkan bahwa dalam pembelajaran yang menggunakan strategi pembelajaran berbasis VBA Microsof Excel dapat meningkatkan kemampuan generalisasi matematik dan self-concept siswa dan menjadikannya lebih baik dari siswa yang memperoleh pembelajaran biasa.
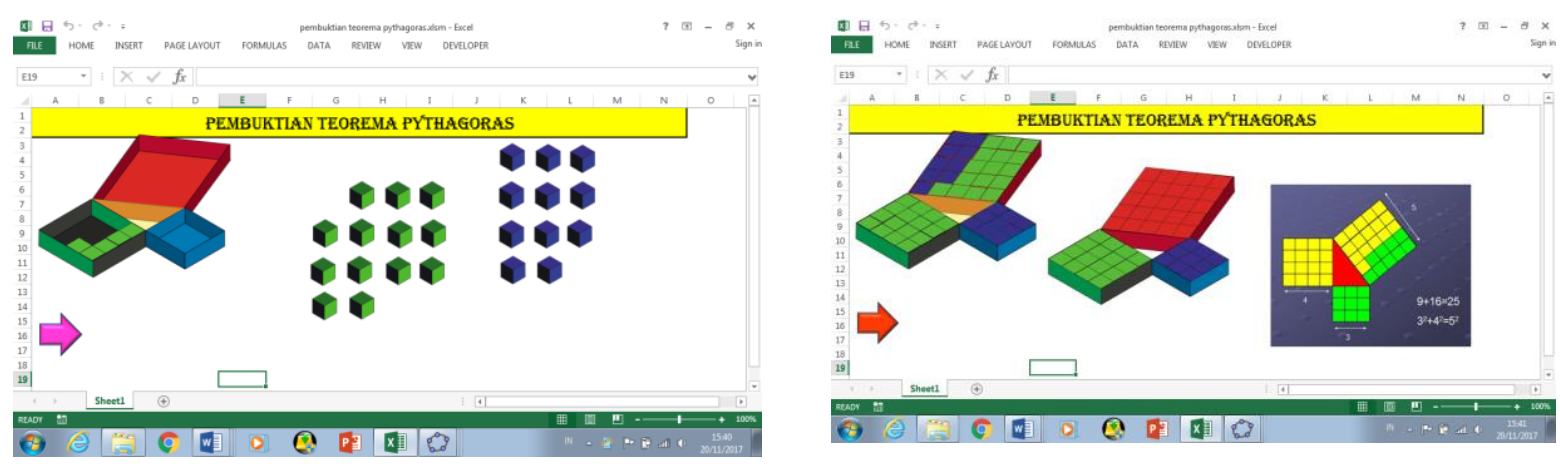

Gambar 1. Tampilan Media Pembelajaran Matematika Berbasis VBA Microsoft Excel 

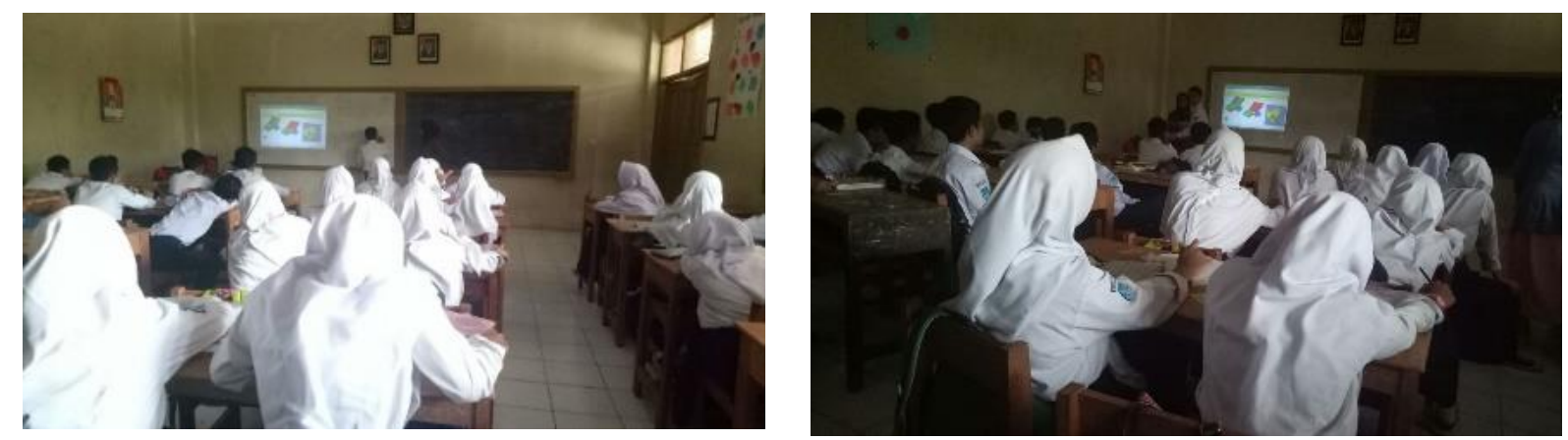

Gambar 2. Siswa fokus memperhatikan pembelajaran dan diberikan kesempatan mencoba media serta menjawab soal di depan kelas

\section{KESIMPULAN}

Dari seluruh rangkaian penelitian yang telah dilakukan mulai dari persiapan, pelaksanaan, sampai pengelolaan data disimpulkan bahwa: (1) Terdapat asosiasi antara kemampuan generalisasi matematik dengan self-concept pada siswa yang pembelajarannya berbasis VBA Microsoft Excel; (2) Tidak terdapat asosiasi antara kemampuan generalisasi matematik dengan self-concept pada siswa yang menggunakan pembelajaran biasa sebagai perlakuan; (3) Self-concept siswa di klasifikasikan masih tergolong cukup ke bawah ditunjukkan dengan koefisien korelasinya.

\section{DAFTAR PUSTAKA}

Arifin, A., \& Nuroso, H. (2011). Pemanfaatan Microsoft Excel untuk Media Pembelajaran Fisika Pokok Bahasan Gerak dengan Bantuan Camtasia Studio 4 1. JP2F, 2(1), 78-88.

Ario, M. (2016). Analisis Kemampuan Penalaran Matematis Siswa SMK Setelah Mengikuti Pembelajaran Berbasis Masalah. Jurnal Ilmiah Edu Research, 5(2), 125-134.

Haerudin. (2013). Pengaruh Pendekatan SAVI Terhadap Kemampuan Komunikasi dan Penalaran Matematik Serta Kemandirian Belajar Siswa SMP. Jurnal Ilmiah Program Studi Matematika STKIP Siliwangi Bandung, 2(2), 183-193.

Hendriana, H., Rohaeti, E. E., \& Hidayat, W. (2017). Metaphorical Thinking Learning and Junior High School Teachers' Mathematical Questioning Ability. Journal on Mathematics Education, 8(1), 55-64.

Hendriana, H., Hidayat, W., \& Ristiana, M. G. (2018, January). Student teachers' mathematical questioning and courage in metaphorical thinking learning. In Journal of Physics: Conference Series (Vol. 948, No. 1, p. 012019). IOP Publishing.

Hendriana, H., Rohaeti, E. E., \& Sumarmo, U. (2017). Hardskills dan Softskills Matematik Siswa. (N. F. Atif, Ed.) (1st ed.). Bandung: PT Refika Aditama.

Lestari, W. D. (2015). Kesulitan Siswa Kelas VII Dalam Menyelesaikan Soal Kemampuan Generalisasi Matematis Pada Materi Segitiga. UNWIR, 7(2), 75-85.

Muyana, S. (2017). Profil Self-Concept Akademik Mahasiswa Baru Program Studi Bimbingan dan Konseling. Jurnal Konseling Gusjigang, 3(1), 85-89. 
Nurhayati. (2015). Penggunaan Media Animasi Berbasis Visual Basic (VBA) Spreadsheet Excel untuk Meningkatkan Penguasaan Konsep Mahasiswa Pada Materi Potensial Osilator Harmonik Sederhana. Jurnal Edukasi Matematika Dan Sains, 3(1), 33-44.

Nuridawani, Munzir, S., \& Saiman. (2015). Peningkatan Kemampuan Penalaran Matematis dan Kemandirian Belajar Siswa Madrasah Tsanawiyah ( MTs ) melalui Pendekatan Contextual Teaching and Learning ( CTL ). Jurnal Didaktik Matematika, 2(2), 59-71.

Rahman, R. (2010). Pengaruh Pembelajaran Berbantuan Geogebra Terhadap Kemampuan Berpikir Kreatif dan Self-concept Siswa. Jurnal: UPI Bandung.

Rayani, D. (2017). Pengaruh Pembelajaran Matematika Dengan Strategi REACT Terhadap Kemampuan Pemecahan Masalah dan Self- Concept Matematis Siswa SMP. Universitas Pasundan.

Ruseffendi, E. T. (2010). Dasar-Dasar Penelitian Pendidikan dan Bidang Eksakta Lainnya (Cetak Pert). Bandung: Tarsito.

Soekadijo. (2003). Logika Dasar Tradisional, Simbolik, dan Induktif (Cetak 9). Jakarta: Gramedia Pustaka Utama.

Supandi, I. (2017). Analisis Kemampuan Penalaran Generalisasi Matematis Siswa Kelas VIII MTs Annajah Pada Materi Segitiga dan Segiempat. Universitas Islam Negeri Syarif Hidayatullah.

Wahyuddin. (2017). Penerapan Model Pembelajaran Numbered Head Together ( NHT ) pada Siswa Kelas V SD Negeri 75 Ujungpero Kecamatan. Suska Journal of Mathematics Education, 3(1), 57-66.

Widiarti, P. W. (2017). Konsep Diri ( Self Concept ) dan Komunikasi Interpersonal. INFORMASI Kajian Ilmu Komunikasi, 47(1), 135-148.

Yuliani, A. (2011). Meningkatkan Kemampuan Analogi dan Generalisasi Matematis Siswa SMP Dengan Model Pembelajaran Inkuiri Terbimbing. Universitas Pendidikan Indonesia. 
382 Pertiwi, Jayanti, \& Afrilianto, Asosiasi antara Kemampuan Generalisasi Matematik ... 